\title{
The Economic Traits and Adaptive Capacity of Bull-calves of the Kazakh White-headed Breed to the Conditions of the Semidesert Zone of the Naryn Sands
}

\author{
Amanzhol Z. Zinullin, Rashid S. Sadykov, Serik A. Alimbekov, \\ Aliya B. Akhmetalieva and Aruzhan E. Nugmanova
}

West Kazakhstan Agrarian - Technical University named after Zhangir Khan, 51, Zhangir Khan Str., Uralsk, 090009, Republic of Kazakhstan.

http://dx.doi.org/10.13005/bbra/2066

(Received: 10 January 2016; accepted: 19 February 2016)

\begin{abstract}
Bull-calves of the Kazakh white-headed breed play leading role in the development of beef cattle farming in Kazakhstan. Therefore, its improvement affects the production volume of high quality beef. The article describes some technological aspects of livestock management in the semidesert zone of the Naryn Sands of Kazakhstan. The authors determined the level of economic traits of the Kazakh white-headed bull-calves, their clinical and physiological parameters as well as the characteristics of hair-coat cover under the conditions of semidesert zone of the Naryn Sands. Three experimental groups of 10 calves in each group were selected for the tests. Bull-calves were selected based on the method of group analogues. According to the research conducted, when implementing management based on traditional technology of livestock, adopted for the Naryn Sands climatic conditions, it is recommended to feed bull-calves aged from 9 to 12 months with supplementary $3 \mathrm{~kg}$ of concentrated feedstuff during the growing period to achieve high live weight. Besides, based on data analysis, it was concluded that under the conditions of the Naryn Sands, there is no need to build facilities for beef cattle management that is economically advantageous. The analysis of the obtained data on hair-coat covering and clinical and physiological parameters suggests strong adaptive capacity of the Kazakh white-headed bull-calves at the conventional management technology typical for the Naryn Sands.
\end{abstract}

Key words: beef breed, young stock management technology, live weight, hair-coat covering, clinical and physiological parameters.

Beef cattle farming, along with horse breeding and sheep breeding in Kazakhstan has always been considered the traditional livestock enterprise.

To increase the population of cattle, as well as to enhance the production of livestock products it is necessary to develop livestock breeding. In the years of reforms there has been a reduction in the population of cattle, and recession of level of selection-breeding work aimed at

* To whom all correspondence should be addressed. improving pedigree and productive qualities of animals. In terms of market conditions and competition it is necessary to restore and develop livestock breeding, because the breeding of animals increases the economic efficiency of livestock production (Alpeisov S.A., 2009).

A beef cattle farming is a specialized industry focused on production of quality beef, which is based on breeding of specialized beef breeds. In beef cattle farming, the most widespread is the Kazakh white-headed breed, whose population in the Republic of Kazakhstan amounts to 53.740 thousand animal units (81.0\%) (Kazhgaliyev N.W., 2010). 
The accelerated development of beef cattle farming has no alternative and it should be considered as the problem of national importance. Its successful solution will eventually meet the effective demand for beef at the expense of domestic production, which will be developed on scientifically grounded reasonable basis for the convenience of the whole population (Lubkov A.N. et al., 2009).

The solution to this task requires increasing the efficiency of using available cattle breed resources. This is particularly true for the widespread Kazakh white-headed breed. In this regard, the issues of cattle breed testing are of paramount importance, because they make it possible to reveal the relevance of individual species to the challenges of beef cattle development in a particular geographic zone. Therefore, there is no doubt concerning the importance of exploring adaptive capacity, productivity and beef-making qualities of bullcalves of the Kazakh white-headed breed to assess the further prospects of its breeding (Gelunova O. B., 2011).

The West Kazakhstan region largely consists of steppe plain and semidesert zone of the Naryn Sands (Akhmetov K.G. et al., 2004). Natural climatic conditions of these two zones are very different. In this regard, there are two historically developed technological approaches to beef cattle farming. However, in the scientific literature only generally accepted technology of beef cattle farming is studied and described in relation to the steppe zone. Nevertheless, in the Naryn Sands, a special technology of cattle farming in winter time was developed, which is successfully used so far. This technology is unconventional for the primary zone of beef cattle farming, though in the meantime it is traditional for the Naryn Sands. At the same time the need for enhancement of the cattle farming, particularly the creation and development of breeding base, requires improvement of certain elements of beef cattle farming technology in relation to the naturalclimatic conditions of the Naryn Sands (Nazarbaev E. et al., 2015).

The main purpose of the current research was to determine the level of economic traits and the adaptive capacity of bull-calves of the Kazakh white-headed breed in the current technological conditions of semidesert zone of the Naryn Sands. Material and research methodology

Beef cattle farming technology uses the ability of animals to adapt to changing environmental conditions. This allows managing them in winter time and bad weather in open houses rather than in hard-wall buildings (Lebedko, E. Ya., 2014). However, in the winter, animals in the Naryn Sands are managed in the open air, in natural "shallow pits" created in the old days by wandering sands and consolidated over the years due to dense vegetation. The depth of these natural "shallow pits" reaches up to 10 meters and the diameter is about 50 meters or even more. Various cereal grasses, licorice and cane of up to 3 meters in height, growing there, efficiently protect the animals against strong winds and frosts during the harsh winter. In these "shallow pits" animals are fed with hay one to two times a day, depending on the condition of winter pastures. Remnants of hay serve irremovable litter. Watering of animals is provided from pit wells by means of centrifugal or chain pumps with horse troughs attached to them.

Noted natural and related technological features of the beef cattle breeding of the Kazakh white-headed breed in the Naryn Sands generate the need to study the effectiveness of spontaneously developed technology. To conduct relevant research, herd of cattle typical for the Naryn Sands was selected from "Akhmetov" peasant agriculture.

Peasant agriculture "Akhmetov" breeds the Kazakh white-headed bull-calves. It is situated at a distance of $600 \mathrm{~km}$ southwest from the regional center - the city of Uralsk.

Three experimental groups of 10 bullcalves in each group were selected for the experiment. Bull-calves were selected based on the group analogues method of. When forming groups, selection of bulls was based on the health status of animal (Table 1).

Three groups differed from each other by handling and feeding conditions. Bull-calves of the group I and III were handled in winter in shallow pits in the open air. However, bull-calves of the group III during the growing period (9-12 months) were fed with supplementary $3 \mathrm{~kg}$ of barley. Bullcalves of the group II were kept in open house and also fed with supplementary $3 \mathrm{~kg}$ of barley during the growing period. 
To study bull-calves' growth and development, they were weighted every month before feeding and watering. Based on these measurements, the average daily increase in body weight was calculated.

Variations in hair-coat covering were studied during both winter and summer seasons. Hair samples were taken in the middle part of the last rib from the area of $1 \mathrm{~cm}^{2}$. Hair mass, density, structure, length and thickness were determined by the standard technique adopted in sheep breeding (Arzumanyan, E.A., 1950).

Physiological studies aimed at measuring body temperature, pulse rate and breathing rhythm, skin and hair-coat coverings were carried out in the summer and winter months. The temperature of bull-calves in the experimental groups was measured by veterinary thermometer in the rectum. Pulse rate was measured by overlaying a finger on the femoral artery. Breathing rhythm was determined by chest movements and expiratory air beat that was felt by the hand approached to the nostrils of the animal.

All experimental material was processed with the use of biometric methods of variation statistics according to the techniques of N.P. Plokhinsky (1969) and E.K. Merkur'eva (1983) using the Microsoft Office Excel (2003).

\section{Some biological features of bull-calves of the} Kazakh white-headed breed

Agricultural animals in ontogenesis are exposed to numerous environmental factors. The degree of influence of these factors on a living organism depends on the level of perfection of adaptive mechanisms, which represent a comprehensive physiological complex involving all organs and systems. Therefore, serious attention has been paid to the study of the level of adaptive mechanisms perfection under specific natural and economic conditions.

As already noted, the the Kazakh whiteheaded breed is the most numerous in beef cattle farming. Due to the high adaptive capacity to harsh conditions of the dry steppes, the Kazakh whiteheaded cattle are used moderately in increasing beef production and improving beef-making qualities (Zhuzenov Sh.A. et al., 2006; Dzhulamanov K.M., 2006). Therefore, when developing and improving lines and types of the Kazakh white-headed breed particular importance should be given to their adaptive capacity to harsh climatic conditions. Besides, a study of adaptive mechanisms, improving animals' resistance to certain factors under extreme conditions will allow obtaining certain data to predict animals' adaptive capacity (Cherekaev V.A., 2000).

\section{Research findings}

The growth and development of bullcalves of the Kazakh white-headed breed in the Naryn Sands

The development level of young stock is the main indicator in the assessment of beef production of a particular group of animals. Therefore, the study of animals' growth and development plays a primary role in the assessment of economic traits of beef cattle.

In terms of biology, the growth as a process of increasing the total mass of body cells, its tissues and organs over time, may be determined on the basis of age-related changes of live weight that in a certain way influence the formation of productive qualities of young stock (Zhuzenov Sh.A. et al., 2006). Thus, the study of the timebased behavior of live weight of bull-calves, grown in the semidesert zone of the Naryn Sands, was of specific interest.

The growth and development of young stock is influenced by various environmental factors. At that, the optimum environmental conditions contribute to the display of the animal's genotype. As known, productive qualities of animal under the same conditions of the outside environment are determined by its genetic abilities.

The analysis of experimental data indicates the inter-group differences in live weight by the end of 12 months of age (Table 2, Fig. 1).

Bull-calves of the group II, which were kept in winter time in open house and were fed over growing period with supplementary $3 \mathrm{~kg}$ of barley, gained during the entire test period $72.9 \mathrm{~kg}$. But, at the same time, bull-calves, which also received $3 \mathrm{~kg}$ of barley, but were kept in shallow pits gained weight by $97.2 \mathrm{~kg}$. Thus, we may conclude that when managing animals during the growing period from 9 to 12 months of age according to the conventional technology adopted in the Naryn Sands, we should feed them with supplementary $3 \mathrm{~kg}$ of barley that will insure their body weight gain by $33.3 \%$.

This advantage was preserved after the 
growing period of up to 18 months of age. Bullcalves of the group III ranging in the age from 12 to 18 months have shown better weight gain than those in the group I ( $35.1 \mathrm{~kg}$ or $37.3 \%$ ). During the period from 9 to 18 months of age bull-calves of the group III increased live weight by 35.5\% (59.4 $\mathrm{kg})$. As a result, at 18 months of age, live weight of bull-calves in the group III amounted to $451.2 \mathrm{~kg}$. This is consistent with the standards on live weight of bull-calves of the Kazakh white-headed breed at the age of 18 months.

According to the scientific-research work methodology, it is necessary to assess the effectiveness of the livestock management technology in the Naryn Sands in comparison with the conventional beef cattle management technology. For these purposes, as stated above, three groups of bull-calves were selected. Bullcalves of the groups II and III during the growing period received supplementary $3 \mathrm{~kg}$ of barley. However, in the winter time, bull-calves of the group II were kept in open house that was not traditional for the Naryn Sands, while bull-calves of the group III were kept in shallow pits like all other animals in the Naryn Sands. Bull-calves of the group III aged from 9 to 12 months were superior to their counterparts in the group II in terms of live weight, which exceeded by $11.5 \mathrm{~kg}$ (13.4\%), while in summer time - by $16.1 \mathrm{~kg}$, respectively. The live weight of the bull-calves in

Table 1. Experimental design

Groups $\begin{aligned} & \text { The age of the } \\ & \text { animals at the } \\ & \text { beginning of the } \\ & \text { experiment }\end{aligned}$
$\begin{aligned} & \text { animals } \\ & \text { Handling and feeding conditions }\end{aligned}$

\begin{tabular}{llll}
\hline I & 8 & 10 & Shallow pits; 8-18 months, hay, barley - 0 kg \\
II & 8 & 10 & $\begin{array}{l}\text { Open housing; 9-12 months, hay, pasture grass, barley - 0 kg; } \\
\text { III }\end{array}$ \\
& 10 & $\begin{array}{l}\text { Shallow pits; 9-12 months, hay, barley - 3 kg; 12-18 months, } \\
\text { hay, pasture grass, Barley - 0 kg; }\end{array}$ \\
\hline
\end{tabular}

Table 2. Bull-calves live weight dynamics ( $\mathrm{x} \pm \mathrm{SX}$ )

\begin{tabular}{lccc}
\hline $\begin{array}{l}\text { Age in } \\
\text { months }\end{array}$ & \multicolumn{3}{c}{ Groups } \\
\cline { 2 - 4 } & I & II & III \\
\hline 8 & $194.6 \pm 2.8$ & $195.2 \pm 2.7$ & $193.0 \pm 2.5$ \\
9 & $218.6 \pm 2.4$ & $223.8 \pm 2.4$ & $224.9 \pm 1.7$ \\
12 & $291.5 \pm 2.5$ & $309.5 \pm 3.0$ & $322.1 \pm 4.3$ \\
15 & $328.0 \pm 5.3$ & $357.5 \pm 6.1$ & $378.3 \pm 5.3$ \\
18 & $385.5 \pm 4.7$ & $422.5 \pm 9.0$ & $451.2 \pm 7.8$ \\
\hline
\end{tabular}

the group III aged from 9 to 18 months was higher than that of the bull-calves in the group II by $27 \mathrm{~kg}$ (13.8\%).

During the entire test period, bull-calves of the group III, which were kept in shallow pits and fed with supplementary $3 \mathrm{~kg}$ of barley, have shown intense growth. Thus, based on data analysis it can be concluded that under the conditions of the Naryn Sands there is no need to build special facilities for beef cattle. Genetic factors

Table 3. Parameters and structure of hear-coat covering of bull-calves taken from $1 \mathrm{~cm}^{2}$ of skin depending on the seasons of the year $(\mathrm{x} \pm \mathrm{Sx})$

\begin{tabular}{|c|c|c|c|c|c|c|}
\hline \multirow{2}{*}{$\begin{array}{l}\text { Groups / } \\
\text { Indicators }\end{array}$} & \multicolumn{2}{|c|}{ Group I } & \multicolumn{2}{|c|}{ Group II } & \multicolumn{2}{|c|}{ Group III } \\
\hline & Winter & Summer & Winter & Summer & Winter & $\overline{\text { Summer }}$ \\
\hline Mass, mg & $79.4 \pm 1.72$ & $18.8 \pm 0.61$ & $80.5 \pm 1.06$ & $18.7 \pm 0.72$ & $81.7 \pm 1.47$ & $19.2 \pm 0.83$ \\
\hline Length, mm & $40.6 \pm 1.44$ & $10.5 \pm 0.62$ & $41.1 \pm 0.87$ & $10.9 \pm 0.60$ & $41.4 \pm 0.82$ & $11.2 \pm 0.51$ \\
\hline Quantity & $1739 \pm 24.39$ & $1051 \pm 21.99$ & $1760 \pm 27.73$ & $1104 \pm 37.41$ & $1788 \pm 42.41$ & $1132 \pm 39.85$ \\
\hline \multicolumn{7}{|c|}{ Structure of hair-coat covering } \\
\hline Beard hair, \% & $16.1 \pm 0.67$ & $42.5 \pm 0.88$ & $16.4 \pm 0.49$ & $44.2 \pm 0.81$ & $17.0 \pm 0.59$ & $44.9 \pm 0.86$ \\
\hline Fluff, \% & $69.8 \pm 1.13$ & $15.6 \pm 1.02$ & $70.2 \pm 1.59$ & $16.4 \pm 0.93$ & $70.9 \pm 0.82$ & $17.1 \pm 0.94$ \\
\hline Transient hair, \% & $14.1 \pm 0.52$ & $41.9 \pm 0.64$ & $13.4 \pm 0.47$ & $39.4 \pm 0.73$ & $12.1 \pm 0.58$ & $38.0 \pm 0.61$ \\
\hline
\end{tabular}


of cattle of the Kazakh white-headed breed have influenced the formation of live weight and body build characteristics of young animals. Bull-calves productivity was influenced by both the feeding level and the genotype of the animals.

Seasonal dynamics of changes in hair-coat covering of bull-calves of the Kazakh white-headed breed in the Naryn Sands

Hair-coat covering performs several important body functions. A number of authors indicated that the thermal (heat, cold, light) and mechanical irritation of the skin via the nervous system has an impact on the physiological processes occurring in the body, as well as trigger adaptive reactions of the organism. Also, in many studies, scientists noted the important thermoregulatory role of animals' hair-coat covering (Muchnik, S.G., 1957).

Hair-coat covering has a particular importance for cattle farmed in areas with sharply continental climate. Under the conditions of sharply continental climate it is desirable that hair-coat covering in warmer months was minimal and conducive to convection, therefore providing cooling of the body. In winter, on the contrary, it is desirable that the hair-coat covering was dense enough to limit heat loss to a minimum (Yakovleva V. I., 1958).

Beef cattle breeds have good adaptive capacity to different natural climatic zones. Thanks to good stamina and ability to endure low temperatures they can be kept in cheap open houses (Bakharev A.A., 2011).

The body's response to external environment is of great interest when solving problems associated with the naturalizing of animals. To this end, we studied the development of hair-coat covering in bull-calves of the Kazakh white-headed breed depending on the season of the year. At that, we determined the number and weight of hair per unit area of skin, hair length and structure.

The data in Table 3 show that no significant differences were found between bullcalves in various groups in terms of hair-coat covering. However, bull-calves in the group III were superior to their counterparts of the groups I and II in terms of weight, length and amount of hair both in the winter and summer seasons (Table 3 ). At the same time, the differences in the hair parameters of the bull-calves in the group III was not statistically significant $(\mathrm{P}<0.90)$.

The data shown in Table 3 indicate large seasonal changes in structure of bull-calves hair in each of the three groups that indicates their good adaptation to the conditions of sharply continental climate of the Naryn Sands. In winter, the hair structure of the bull-calves in the group III was characterized by a high content of fluff in comparison with the bull-calves from the groups I and II. A characteristic feature of the Kazakh whiteheaded breed is high content of fluffy fibers in the

Table 4. Body temperature, pulse rate and breathing rhythm of bull-calves ( $0 \pm S x)$

\begin{tabular}{lllll}
\hline \multirow{2}{*}{ Clinical score } & The time & \multicolumn{3}{c}{ Groups } \\
\cline { 3 - 5 } & of day & Group I & Group II & Group III \\
\cline { 3 - 5 } & & & & \\
Winter & morning & $38.5 \pm 0.1$ & $39.1 \pm 0.1$ & $39.3 \pm 0.1$ \\
Body temperature, ${ }^{\circ} \mathrm{C}$ & afternoon & $39.0 \pm 0.1$ & $39.3 \pm 0.1$ & $39.4 \pm 0.1$ \\
& morning & $91.4 \pm 2.4$ & $89.5 \pm 3.4$ & $87.1 \pm 2.5$ \\
Pulse rate & afternoon & $94.7 \pm 2.9$ & $88.2 \pm 3.0$ & $90.2 \pm 3.5$ \\
& morning & $18.7 \pm 2.1$ & $21.4 \pm 1.8$ & $22.6 \pm 1.4$ \\
Breathing rhythm & afternoon & $24.1 \pm 1.6$ & $25.7 \pm 1.3$ & $25.6 \pm 1.0$ \\
& & & & \\
Summer & morning & $39.2 \pm 0.1$ & $39.0 \pm 0.1$ & $39.1 \pm 0.1$ \\
Body temperature, ${ }^{\circ} \mathrm{C}$ & afternoon & $39.5 \pm 0.1$ & $39.6 \pm 0.1$ & $39.5 \pm 0.1$ \\
& morning & $68.8 \pm 2.9$ & $70.6 \pm 2.1$ & $71.3 \pm 2.1$ \\
Pulse rate & afternoon & $74.5 \pm 3.3$ & $78.9 \pm 2.6$ & $75.3 \pm 1.9$ \\
Breathing rhythm & morning & $28.5 \pm 1.4$ & $29.0 \pm 1.2$ & $27.6 \pm 1.7$ \\
& afternoon & $43.6 \pm 2.1$ & $41.4 \pm 1.2$ & $44.5 \pm 1.3$ \\
\hline
\end{tabular}


hair sample both in winter and summer seasons. Therefore, bull-calves of the Kazakh white-headed breed kept under the conditions of semidesert zone are characterized by well-developed hair-coat covering.

Thus, the analysis of the material obtained indicates good adaptive capacity of bullcalves of the Kazakh white-headed breed at the traditional management technology adopted in the Naryn Sands.

Physiological state of bull-calves of the Kazakh white-headed breed depending on environmental conditions

When evaluating the adaptive capacity of the livestock in terms of its breeding under different climatic conditions, it is important to study clinical indicators of the animals such as body temperature, pulse rate and breathing rhythm.

Startsev, A.I. (1956) believed that the pulse rate is one of the most important indicators of general body condition. Dürst I. (1936) has found that body temperature, pulse rate and breathing rhythm vary with age, gender, and physiological condition of the animals, as well as the feeding regime and environmental conditions.

Pulmonary ventilation and breathing rhythm of animals in winter is reduced, and this should be considered as an important adaptive ability of animals associated with thermoregulation (Dorotiuk E. N. et al., 1975). The change in these indicators occurs as a result of adaptation of imported animals to local climatic conditions (Vinogradov, I. I. et al., 2008).

The rate of pulmonary ventilation has a direct relationship with animal's growth rate. The higher the absolute value of ventilation rate, the higher the live weight gain (Prakhov P. L. et al., 1990).

In winter time at sub-zero ambient temperatures, breathing rhythm of animals decreases that limits the heat loss through pulmonary ventilation. At the same time, the pulse rate increases and a slight increase in body temperature is observed. The increase in pulse rate results in increased blood flow rate to the peripheral parts of the body that improves their heating. Increased pulse rate at sub-zero temperatures, obviously, is associated with a growing demand of tissues in oxygen and nutrients.

In summer, high temperature of the ambient air causes an increase in body temperature, pulse rate and breathing rhythm.

The results of observations on variations in body temperature, pulse rate and breathing rhythm in tested bull-calves under different environmental conditions (winter and summer) are shown in Table 4.

Clinical and physiological indicators of bull-calves in all three groups were determined in January and July. In the winter when the outdoor temperature was $-25^{\circ} \mathrm{C}$ and at wind speed of $4 \mathrm{~m} / \mathrm{s}$ the average body temperature of the animals in the morning was $38.5,39.1$ and $39.3^{\circ} \mathrm{N}$, respectively; while at noon it was $39.0,39.3$ and $39.4^{\circ} \mathrm{C}$, respectively. In general, the bull-calves' body temperature at noon has raised by $0.1-0.5^{\circ} \mathrm{C}$ as compared to morning temperatures. The bull-calves of the group III showed lower temperature fluctuations. Fluctuations of body temperature are related to ambient temperature. The bull-calves of

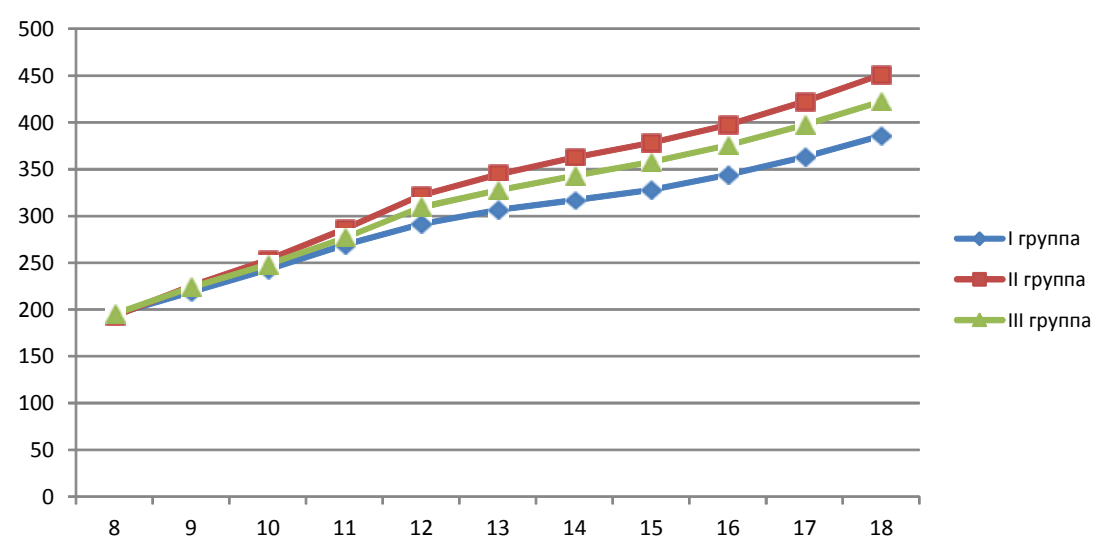

Fig. 1. The distribution of live weight of young animals in I, II and III groups for the entire test period. (Group I, Group II, Group III) 
the group I were subjected to relatively large fluctuations in body temperature at noon as compared to morning temperatures (increased by $0.5^{\circ} \mathrm{C}$ ). The bull-calves of the group I and III were kept outdoors in shallow pits. However, bull-calves of the group I did not receive supplementary feeding, and thus they have relatively low fatness and the subcutaneous fat. The data in Table 3 show also that the number of hairs from $1 \mathrm{~cm}^{2}$ and the percentage of fluff of bull-calves in the group I are lower as compared to proper figures for the bullcalves of the group III. All this is due to the low nursing level with no supplementary feeding. The level of adaptive capacity of animals towards low temperatures is directly related to the level of feeding, even for the animals with the same genotypes. When managing the bull-calves of the Kazakh white-headed breed at an open air in winter time according to the traditional technology adopted in the Naryn Sands, it is necessary to feed them with supplementary $3 \mathrm{~kg}$ of barley to preserve homeostasis. The bull-calves of both groups II and III received supplementary feeding. However, they were kept in open houses, and thus their adaptive capacity to low temperatures was relatively low as compared to the bull-calves of the group III. The body temperature of the bullcalves at noon increased by $0.2^{\circ} \mathrm{C}$ as compared to the morning temperatures, while breathing rhythm decreased by $18.6 \%$, and pulse rate increased by $1.3 \%$. The pulse rate of the bull-calves of the group III at sub-zero temperatures was somewhat higher in the morning, slightly decreasing by the afternoon. This indicates the fact that at sub-zero temperatures moderate cardiac activity provided normal physiological state of the organism. However, to maintain the normal physiological state of the body bull-calves of the group I experiences slightly greater cardiac stress (91.4 in the morning, while 94.7 at noon) than the bull-calves of the groups II and III.

In summer clinical and physiological indicators of the bull-calves of all three groups were satisfactory. Body temperature of the bullcalves in the group III has increased by $0.45^{\circ} \mathrm{C}$ due to the increase of external air temperature. Bullcalves of the group III experienced lower temperature fluctuations. The adaptive capacity of the bull-calves of the groups II and III, which received supplementary feeding, was relatively higher in comparison to the bull-calves of the group I, because of well developed subcutaneous fat.

The research findings showed that in winter and summer seasons the bull-calves of the Kazakh white-headed breed felt satisfactorily that, in turn, indicates a good adaptive capacity of these animals to the conditions of a semidesert zone of the Naryn Sands.

\section{CONCLUSION}

The Kazakh white-headed cattle, as unpretentious and unique source of genetic material, are necessary for beef cattle farming development. The potential for increasing the beef herd in Kazakhstan lies in the development of sands in semidesert regions. The analysis of live weight indicators showed that the young stock has good productivity.

To increase live weight of young stock at the traditional housing technology adopted under the conditions of the Naryn Sands, it is recommended to give bull-calves supplementary 3 $\mathrm{kg}$ of concentrated feedstuff (barley) during the period of growing from 9 to 12 months. Also, based on the data analysis it can be concluded that under the conditions of the Naryn Sands there is no need to build special facilities for keeping beef cattle. Genetic factors of the Kazakh white-headed breed cattle have influenced the formation of live weight and body build characteristics of young animals.

The analysis of the obtained data on the hair-coat covering as well as clinical and physiological parameters suggest strong adaptive capacity of bull-calves of the Kazakh white-headed breed at the management based on traditional technology adopted in the Naryn Sands.

\section{ACKNOWLEDGEMENTS}

We express our gratitude to Nurbolat Akhmetov, the head of the peasant agriculture, for providing assistance and help in conducting of research work.

\section{REFERENCES}

1. Alpeysov, Sh.A., "Current Status of Cattle Breeding and its Science-Based Development 
Prospects," Bulletin of Agriculture of Kazakhstan, 2009; 3: 37-38.

2. Kazhgaliyev, N.Zh., "The Analysis of the Current State and Development Prospects of Beef Cattle Breeding in the Republic of Kazakhstan,” Bulletin of the Orenburg State Agrarian University, 2010; 28(4): 108-110.

3. Lubkov, A.N., Romashin, M.S., and Kostrov, V.O., "Strategy of Accelerated Development of Beef Cattle Breeding: Problems and Solutions," Agrarian Bulletin of the Urals, 2009; 6: 12-14.

4. Gelunova, O.B., "Economic an Biological Features of the Bull-calves of the Kazakh whiteheaded breed, Kalmyk Breed and their Crosses in the Lower Volga Region,” The Scientific Journal of the Kuban State Agrarian University, 2011; 70(06): 1-15.

5. Akhmetov, K.G. et al., “Agriculture System of West Kazakhstan Region,” West Kazakhstan Agricultural and Technical University named after Zhangir Khana, 2004; 4-8.

6. Nasambaev, E.G., Zinullin, A.Z., and Nugmanova, A.E., "The Possibilities of Unconventional Beef Cattle Breeding Techniques in Relation to the Semidesert Zone Conditions of the Naryn Sands,” Ulyanovsk, Ulyanovsk State Agricultural Academy named after P.A. Stolypin, 2015; 247-250.

7. Lebedko, E.Ya., "Large-Scale InvestmentInnovation Megaproject of "Miratorg" Agribusiness on the Development of Specialized Beef Cattle Breeding in the Bryansk Region,” Bryansk, Bryansk State Agricultural Academy, 2014; 5-8.

8. Arzumanyan, A.E., "The Skin of Cattle and its Relationship with Productivity,” Moscow, Proceedings of the all-Union Livestock Research Institute, 1950; 166-188.

9. Plokhinsky, N.A., "Guide to Biometrics for Animal Technicians,” Moscow, Kolos, 1969; 19: 64-69.

10. Merkurieva, E.K., and Shangin-Berezovsky, G.N., "Genetics with the Basics of Biometrics", Moscow, Kolos, 1983; 197-211.

11. Zhusenov, S.A., and Zhusupov, M., "The Evaluation Results of the Kazakh White-headed Bull-calves in Terms of their Production Qualities,” The $1^{\text {st }}$ International Conference on Agriculture, Astana, 2006; 65-66.
12. Dzhulamanov, K.M., "The Influence of Individual Environmental Factors on Weight Gain of Bull-calves of the Kazakh White-headed Breed,” Orenburg Bulletin of Beef Cattle, 2006; 59(1): 76-79.

13. Cherekaev, V.A., "Beef Cattle Farming and its Development Prospects: Beef Cattle Farming of Russia in the XXI Century,” Orenburg, Anniversary Edition of All-Russian Research Institute of Beef Cattle Farming, 2000; 53: 1326.

14. Zhuzenov, S.A., "The Results of a Two-stage Evaluation of Animals in Beef Cattle Farming: Bull-calves in Terms of their own Productivity, and Posteriors Quality Proving,” Bulletin of the Agricultural Science of Kazakhstan, 2006; 1: 3439.

15. Muchnik, S.G., "Skin Covering," Science and Life, 1957; 1: 63.

16. Yakovlev, V.I., "Constitutional and Biological Peculiarities of the Kazakh White Breed Cattle," Proceedings of the Semipalatinsk Veterinary Institute, 1958; 1: 67-84.

17. Bakharev A.A., "Peculiarities of Hair-coat Covering of Beef Cattle Breeds under the Conditions of Northern Trans-Urals," Agrarian Bulletin of the Urals, 2011; 12(2): 8-9.

18. Startsev, I.D., "Main Issues of Breeding. Theoretical Basis and Practical Application of the Cattle Crossbreeding Methods,” Moscow, Selkhozgiz, 1956; 50.

19. Dürst, I., "The Basics of Cattle Breeding," Moscow, Selkhozgiz, 1936; 20-34.

20. Dorotiuk, E.N., and Kayumov F.P., "Beef Productivity of Bull-calves and Steers of the almyk and Kazakh white-headed breeds,” Orenburg,: Issues of Beef Cattle Breeding, 1975; 18: $54-62$.

21. Vinogradov, I.I., and Podoynitsyna, T.A., "Clinical and Physiological Indicators of Bullcalves of the Kazakh White-headed Breed under conditions of Transbaikalia," Far Eastern Agrarian Bulletin, 2008; 3(7): 76-77.

22. Prakhov, L.P., Lushnikov, I. B., and Dorotiuk E.N., "Evaluation of Beef Breeds Bulls in Terms of Progeny Quality and Testing of Bull-calves by Growth Rate, Live Weight, and Beef-making Quality,” Moscow: Agropromizdat, 1990; 17. 